\title{
Telomere-Associated Protein RIF1
}

National Cancer Institute

\section{Source}

National Cancer Institute. Telomere-Associated Protein RIF1. NCI Thesaurus. Code C124094.

Telomere-associated protein RIF1 (2472 aa, $274 \mathrm{kDa}$ ) is encoded by the human RIF1 gene. This protein is involved in DNA damage-induced cell cycle arrest. 